doi:10.18575/msrs.sm.e.16.20 UDK 617.751-072.7

COBISS.RS-ID 6164504

\section{Surgical Treatment of Traumatic Flail Chest - Twenty Years of Experience}

\begin{abstract}
Introduction: Traumatic flail chest is segment of the chest wall, which is caused by multiple fractures or by separation of bone structures (at least three sequential broken ribs or separated into two fracture lines). These injuries are mainly seen in polytrauma patients.
\end{abstract}

Aim of the Study: Our aim is to show the therapeutic benefits of surgical treatment (operative stabilization) of the flail chest.

Patients and Methods: We retrospectively analyzed patients who underwent surgery at the Clinic of Thoracic Surgery, University Clinical Centre of the Republic of Srpska, Banja Luka, in the period from 01. 12. 1997 - 04. 06. 2016.

Results: 50 patients with traumatic flail chest with average age of 47.42 years were surgically treated in the twenty-year period at the Clinic of Thoracic Surgery, University Clinical Centre of the Republic of Srpska, Banja Luka. The average length of a hospital stay was 15 days. Survival rate in the operated group was $91.43 \%$.

Conclusion: If conservative measures such as internal stabilization, the use of analgesics, antibiotics, oxygen therapy and airway toilet does not lead to stabilization of respiratory function, surgical chest wall stabilization is necessary.

Key words: movable flail chest, surgical stabilization

(Scr Med 2016:47:121-124)

\section{Dušan Janičić ${ }^{1}$ Marko Kantar', Ljiljana Krupljanin ${ }^{1}$, Vera Gazdić2, Ostoja Savic ${ }^{3}$}

${ }^{1}$ Clinic of Thoracic Surgery, University Clinical Centre of the Republic of Srpska, Banja Luka

${ }^{2}$ Clinic for Anesthesia and Intensive Therapy, University Clinical Centre of the Republic of Srpska, Banja Luka ${ }^{3}$ Clinic of Neurosurgery, University Clinical Centre of the Republic of Srpska, Banja Luka

Contact address:

Dušan Janičić

Zdrave Korde 1.

$780 o$ o Banja Luka, Republic of Srpska

Bosnia and Herzegovina

Telephone: +38751343237

E-mail: dusan.janicic@gmail.com

Submitted: July 20 ${ }^{\text {th }}, 2016$

Accepted: August 14 ${ }^{\text {th }}, 2016$

\section{Introduction}

Flail chest is post-traumatic thoracic segment of the wall that does not have continuity with the remaining bony skeleton of the chest. It occurs with lost support of at least three ribs in two lines with the trauma. ${ }^{1}$

Pathophysiological disorder occurs due to the paradoxical movement: during inspiration flail chest moves toward the inside of the chest, while it moves outward in the expirium. This reduces the efficiency of breathing and the volume of inhaled air. This condition is followed by typical clinical triad: intrabronchial hemorrhage, ineffective cough and anoxia. $^{1,2}$

Post-traumatic flail chest is a cause of high mortality, especially in polytrauma patients. Early work on the moving flail chest recorded a mortality of up to $80 \% .2$ Standard treatment is focused on the treatment of lung parenchymal injury and pain control, often with the use of mechanical ventilation with positive pressure. Several previous studies have shown that there are multiple benefits of operative, surgical, stabilization of the flail chest. ${ }^{3}$ 


\section{Aim of the study}

The aim of the work consists in the presentation of therapeutic benefits of surgical treatment (operative stabilization) of flail chest.

\section{Patients and Methods}

Hospital records were processed by using the retrospective analysis of data on patients treated at the Clinic of Thoracic Surgery, Clinical Centre of Banja Luka with traumatic flail chest in the period from 01. 12. 1997 - 04. 06. 2016. Both methods described so far: osteosynthesis systems and intramedullary stabilization (Kirschner's wires and wire stitches) were used for stabilization of the flail chest. CT scanning was performed preoperatively to assess the volume of the thoracic trauma. All surgical treatments were performed under general endotracheal anesthesia, used by double-lumen tube by Karlens. Posterolateral thoracotomy with exploration of the pleural cavity was used as an operational method for the treatment of parenchymal lung lesions, intrathoracic hemorrhage and intrapleural clot removal. In the case of laceration of the parenchyma and lesions intrathoracic structures, two intrathoracic drainage were placed in the front and back line, in the fifth and seventh intercostals space.

\section{Results}

Our study covers a twenty-year period, from 01. 12. 1997 04. 06. 2016 during which the Clinic of Thoracic Surgery, University Clinical Centre of the Republic of Srpska, Banja Luka, surgically treated 50 patients with traumatic created flail chest. Surgery was performed on 43 men (86\%) and seven women (14\%). Patients' average age was 47.42 years. In $48 \%$ ( 24 patients), the mechanism of injury was traffic traumatism. Postoperative mortality rate is $8.57 \%$. Causes of mortality are associated comorbidity in the elderly and associated polytrauma (abdominal injury, locomotor system, craniocerebral injury). Survival in the operated group was $91.43 \%$. The average length of hospitalization was 15 days. On 24 patients (48\%), a suture lung parenchyma was performed with the thoracotomy and stabilization of flail chest due to its laceration. Four patients (8\%) underwent an extensive resective surgery of lung parenchyma (lobectomy or bilobectomy type). Six patients (12\%) underwent suture hemidiaphragm due to its laceration. Only six patients (12\%) underwent a fenestration of pericardium. Three patients (6\%) were registered with a chronic postoperative pain.

\section{Discusion}

Prolonged artificial ventilation is still the most commonly used method for the treatment of the unstable segment of the chest wall. ${ }^{2}$

The goal of surgical stabilization of the unstable chest wall is to shorten the time of application of respirators and avoid complications due to its prolonged applications. ${ }^{4}$ Most studies have shown that surgical stabilization leads to a reduction in mortality in thoracic trauma, shortens time in the intensive care unit, and reduces the length of application of mechanical ventilation. ${ }^{2-5}$

Indications for use of this surgical procedure are not yet standardized, but the following are generally accepted by the thoracic surgeons:

- unstable chest wall if there is an indication for thoracotomy due to intrathoracic injury,

- unstable chest wall without contusion of the lung parenchyma,

- paradoxical movements of the unstable segment of the chest wall in patients on a ventilator (PEEP insufficient stabilization),

- extensive deformity of the chest wall.,5

Some authors suggest the following indications:

- the existence of strong pain despite the slight paradoxical movements, which could lead to respiratory insufficiency,

- associated abdominal injuries after splenectomy and disposal rifts diaphragm,

- exploratory thoracotomy due to penetrating wounds. ${ }^{5}$

Advantages of this surgical procedure are:

- pain reduction,

- reduction of the time that a patient spends on a ventilator,

- early extubation of the patient,

- complete reduction of the fracture with perfect anatomical consolidation..$^{2-5}$

Most of thoracic surgeons believe that the extensive posterolateral thoracotomy is the optimal approach, without the need for additional thoractic incisions. ${ }^{6}$

Poor coalesced fractures of ribs in flail chest treated with artificial ventilation, as well as the consequent pain are additional arguments in favor of the rib fixation. ${ }^{6}$

The average age of treated patients in our series was 47.42 years, slightly lower than in the literature, which states the average age of 52 years. 
The average length of hospital stay which is mentioned in the literature is fifteen days; our results are consistent with the allegations in the professional literature.

Authors state that the average survival after operative treatment of patients with traumatic flail chest above $78 \%$. Survival in our series of surgically treated patients with traumatic flail chest is slightly larger than the specified percentage of the scientific literature and is $91.43 \%$. A possible explanation is, partially, in lower average age of treated patients.

Most authors consider that the operational stabilization flail chest of the chest wall can be done in the first seven days after injury. In mentioned series of patients, operative stabilization of the flail chest of the chest wall is made within four days of injury, in most patients the first or second day of the injury.

\section{Conclusion}

Flail chest is a serious therapeutic problem which, if not treated appropriately, leads to disturbances in ventilation and gas exchange and ultimately to respiratory failure.

If conservative measures such as the inside stabilization, the use of analgesics, antibiotics, oxygen therapy and airway toilet does not lead to a stabilization of respiratory function, surgical stabilization of the chest wall is necessary.

Such a relatively simple surgical procedure is far less risky compared to all the complications that can arise without it, increases the survival rate and significantly reduces hospitalization.

\section{Reference}

1. I. Leenen : Special Issue on rib fixation; Eur J Trauma Emerg Surg,DOI 10.1007/s ooo68-010-0049-2,Published on line September 2010.

2. M. Bemelman, M. Poeze, T. J. Blokhuis, L. P. H. Leenen: Historic overview of treatment techniques for rib fractures and flail chest; Eur J Trauma Emerg Surg,DOI 10.1007/s ooo68-010-0046-5, Published on line 23 September 2010.

3. M. Bottlang, S. Walleser, M. Noil. et al. : Biomechanical rationale and evaluation ofan implant system $\mathrm{f}$ or rib fracture fixation; Eur J Trauma Emerg Surg,DOI 10.1007/s 00068-010-0047-4, Published on line : 24 September 2010.

4. D. C. Fitzpatrik, P. J. Denard, D. Phelen et al.: Operative stabilization og flail chest injuries : review of literature an fixation option; Eur J Trauma Emerg Surg,DOI 10.1007/s o0o68-010-0027-8, Published on line : 03 June 2010.

5. M. G. Gaspari, W. B. Tisol, G. B. Haaler : Rib stabilization : lessons learned; Eur J Trauma Emerg Surg,DOI 10.1007/s ooo68-010-0048-3, Published on line : 24 September 2010.

6. Andrea Bille, Lawrence Okiror, Wolfram Karenovics and Tom Routldge : Experience with titanium devices for rib fixation and coverage of chest wall defects; Interactive Cardio Vascular and Thoracic Surgery $2012 ; 15$ : 588 595

http://dx.doi.org/10.1093/icvts/ivs327

PMid:22815325 PMCid:PMC3445392 


\section{Hirurški tretman pokretnog kapka - dvadesetogodišnje iskustvo}

\section{SAŽETAK}

Uvod: Traumatski pokretni kapak je segment grudnog zida, koji nastaje višestrukim prelomom ili separacijom koštanih struktura (najmanje tri rebra serijski prelomljena ili odvojena u dvije frakturne linije). Ovakva povreda se najčešće sreće u sklopu politraume.

Cilj rada: Prikazati terapijske prednosti hirurškog tretmana (operativna stabilizacija) pokretnog kapka.

Ispitanici i metode: Retrospektivnom analizom obrađeni su pacijenti operisani na Klinici za torakalnu hirurgiju UKC RS Banja Luka u periodu od 01. 12. 1997. do 04. 06. 2016. godine.

Rezultati: U navedenom dvadesetogodišnjem periodu, na Klinici za torakalnu hirurgiju UKC RS Banja Luka, operativno je tretirano 50 pacijenata sa traumatskim pokretnim kapkom, srednje životne dobi od 47,42 godine. Prosječno trajanje hospitalizacije je 15 dana. Preživljavanje u grupi operisanih je $91,43 \%$.

Zaključak: Ukoliko konzervativne mjere kao što su unutrašnja stabilizacija, primjena analgetika, antibiotika, oksigenoterapija i toaleta disajnih puteva ne dovedu do stabilizacije disajne funkcije, operativna stabilizacija zida grudnog koša je neophodna.

Ključne riječi: pokretni kapak, operativna stabilizacija 